\title{
INFLUENCE OF VARYING NITROGEN LEVELS ON GROWTH, YIELD AND NITROGEN USE EFFICIENCY OF HYBRID MAIZE (Zea mays)
}

\author{
M.A. Majid ${ }^{1}$, M. Saiful Islam², A. EL Sabagh ${ }^{3, *}$, M.K. Hasan ${ }^{7}$, M.O. Saddam ${ }^{7}$, C. Barutcular ${ }^{4}$, \\ D. Ratnasekera ${ }^{5}$, Kh. A.A. Abdelaal $^{6}$ and M.S. Islam ${ }^{7}$
}

\author{
${ }^{1}$ Natore City College, Natore, Bangladesh \\ ${ }^{2}$ Department of Crop Science and Technology, Rajshahi University, Bangladesh \\ ${ }^{3}$ Department of Agronomy, Faculty of Agriculture, Kafrelsheikh University, Egypt \\ ${ }^{4}$ Department of Field Crops, Faculty of Agriculture, Cukurova University, Turkey \\ ${ }^{5}$ Department of Agricultural Biology, Faculty of Agriculture, University of Ruhuna, Sri Lanka \\ ${ }^{6}$ Agricultural Botany Department, Faculty of Agriculture, Kafrelsheikh University, Egypt. \\ ${ }^{7}$ Department of Agronomy, Hajee Mohammad Danesh Science and Technology University, Bangladesh
}

Received - February 27, 2017; Revision - March 31, 2017; Accepted - May 05, 2017

Available Online - May 12, 2017

DOI: http://dx.doi.org/10.18006/2017.5(2).134.142

KEYWORDS
Nitrogen
Yield traits
Yield
Hybrid maize

\begin{abstract}
Present investigation was carried out at Natore Sugar Mills area, Natore, Bangladesh during 2014-15 to evaluate the growth and yield responses of hybrid maize varieties under different levels of nitrogen fertilization. Two hybrid maize varieties viz. BARI hybrid maize-7 and BARI hybrid maize-9 were tested under four nitrogen levels $\left(\mathrm{N}_{0}=\right.$ without external nitrogen supply, $\mathrm{N}_{1}=115 \mathrm{~kg} \mathrm{~N} \mathrm{ha}^{-1}, \mathrm{~N}_{2}=230 \mathrm{~kg}$ $\mathrm{N} \mathrm{ha}^{-1}$, and $\mathrm{N}_{3}=345 \mathrm{~kg} \mathrm{~N} \mathrm{ha}^{-1}$ ). All recommendations agronomic practices were used for both the variety. Yield and yield traits (plant height, plant girth, total leaves plant ${ }^{-1}$, effective leaves plant ${ }^{-1}$, noneffective leaves plant ${ }^{-1}$, total root plant ${ }^{-1}$, straw weight plant ${ }^{-1}$, cob length, grain free cob, cob girth, grain line $\mathrm{cob}^{-1}$, total grain $\mathrm{cob}^{-1}$, grain number line ${ }^{-1}, 1000$-grains weight, grain weight $\operatorname{cob}^{-1}$, grain yield, straw yield and biological yield) were measured during and on the completion of the study. BARI hybrid maize-9 achieved maximum yield $\left(10.99 \mathrm{t} \mathrm{ha}^{-1}\right)$ and it was followed by the BARI hybrid maize-7 (10.37 $\left.\mathrm{t} \mathrm{ha}^{-1}\right)$. Results of study revealed that yield traits and final yield significantly increased with increasing nitrogen fertilizer from 0 to $345 \mathrm{~kg} \mathrm{ha}^{-1}$. Among various tested $\mathrm{N}$-fertilizer doses, highest grain yield was obtained from the plot treated with $\mathrm{N}_{3}$ treatment $\left(345 \mathrm{~kg} \mathrm{ha}^{-1}\right.$ ) but it was not statistically differing from the $\mathrm{N}_{2}$ treatment $\left(230 \mathrm{~kg} \mathrm{ha}^{-1}\right)$. Therefore, $\mathrm{N}_{2}$ treatment $\left(230 \mathrm{~kg} \mathrm{ha}^{-1}\right)$ could be recommended for variety BARI hybrid maize- 9 as the best economical nitrogen level for maximum economical yield of maize.
\end{abstract}

* Corresponding author

E-mail: ayman.elsabagh@agr.kfs.edu.eg (A El Sabagh)

Peer review under responsibility of Journal of Experimental Biology and Agricultural Sciences.

Production and Hosting by Horizon Publisher India [HPI] (http://www.horizonpublisherindia.in/).

All rights reserved.
All the article published by Journal of Experimental Biology and Agricultural Sciences is licensed under a Creative Commons Attribution-NonCommercial 4.0 International License Based on a work at www.jebas.org.

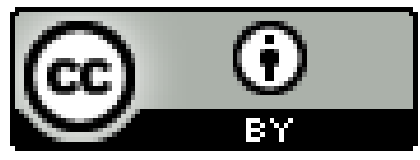




\section{Introduction}

Maize (Zea mays L.) ranked third among the world cereal crop production. Maize is a short duration, quick growing crop and has potential to produce high quantity grains per unit area (Akbar et al., 2008). Maize is grown for grain as well as fodder in tropical, sub-tropical and temperate regions of the world. Maize as a cereal, has multiple uses such as bread making, corn flakes, corn syrup, corn starch, textile, paper making and in other food industries (Kumar \& Jhariya, 2013). Corn oil is suitable for human consumption due to the presence of unsaturated fatty acids (Khan et al., 2013). Average maize yield $\left(6.56 \mathrm{tha}^{-1}\right)$ in Bangladesh is very discouraging farmers, due to the big gap exists between the actual and potential yield per unit area of the crop (AIS, 2017).

The nitrogen plays significant role in various physiological operations of maize. It extends the leaf area effectively, delaying senescence and essential for initiation of ear and kernel. Further, proper nitrogen supply also affect define maize sink capacity (Torbert et al., 2011), maintain functional kernels throughout the grain filling, affecting the number of developed kernels and final size of kernel (Hopf et al., 1992; John \& Schmitt, 2007). The influence of $\mathrm{N}$ availability on essential agronomic traits of maize has been described by several investigations (McCullough et al., 1994; Evans, 2008). Among the various major nutrients required for proper plants, Nitrogen has a key role and particularly it has been proven for maize by various experiments (Subramanian et al., 2006; Carpici et al., 2010). The nitrogen requirement of maize is depend on weather conditions, soil type and crop rotation pattern (Blackmer, et al., 2009; Bundy, et al., 2011).

Nitrogen is considered as the nutrient that most frequently limits yield and plays an important role in quality of maize crops. It is almost deficient in most of the Bangladesh soils and most of the tropics (Jules et al., 2014). Singh et al. (2006) found that the biological yield, content and uptake of nitrogen in grain and straw of maize were highest with supply of nitrogen as urea in two split dressings. Sawi et al. (2013), and Omara \& Kurtz (2009) observed that nitrogen had significant effects on chemical composition of leaves, plant height, number of leaves and internodes per plant, dry weight of shoot and root, cob number per plant, number and weight of cobs $/ \mathrm{m}^{2}$, weight of seeds per cob, final seed yield and straw yield. Gasim et al. (2011) found that the addition of nitrogen increased forage fresh and dry yield and increased crude protein percentage in the leaf and stem indicating vital role of nitrogen particularly on maize. Generally, the agronomic practices and environmental factors have an effect on the growth, yield and quality of maize (Abd el-wahed et al., 2015; Barutcular et al., 2016 a; Barutcular et al., 2016b; EL Sabagh et al., 2015 and EL Sabagh et al., 2017).

So far large numbers of experiments have been carried out throughout the world to find out the optimum level of nitrogen in maize. However, country specific researches have not yet been done on different level of nitrogenous fertilizer especially with hybrid maize varieties under local environmental and soil conditions. Therefore, the present study was undertaken to find out the response of different doses of nitrogen on growth and grain yield, $\mathrm{N}$ use efficiency and other agronomic traits of hybrids maize varieties in Bangladesh.

\section{Materials and Methods}

The experiment was conducted at Natore Sugar Mills area, Natore, Bangladesh during 2014-15 to find out the optimum nitrogen dose for maximum productivity of BARI hybrid maize-7 and BARI hybrid maize-9. The experimental site have non-calcarious dark grey and black flood plain soil (Chalan Bill lower land) under the Chalan Bill flood plain (AEZ 8). The soil of the study area is generally sandy clay loam, non-saline and non-sodic with pH 7.0 (FRG, 2012). The experimental area was under sub-tropical climate characterized by rainfall during the Rabi season (November to April) and low temperature with scanty rainfall during the season.

The treatments of the two factorial experiment consisted as (a) varieties: ( BARI hybrid maize-7, \& BARI hybrid maize-9) and (b) different nitrogen levels viz. (i) Control $\left(\mathrm{N}_{0}\right)$, (ii) $115 \mathrm{~kg}\left(\mathrm{~N}_{1}\right)$, (iii) $230 \mathrm{~kg}\left(\mathrm{~N}_{2}\right)$, and (iv) $345 \mathrm{~kg} \mathrm{~N} \mathrm{ha}^{-1}\left(\mathrm{~N}_{3}\right)$. The nitrogen was applied using urea $(46 \% \mathrm{~N})$. The experiment factors (treatments) were organized in completely randomized block design and the treatments were replicatedthree times. The sowing time was in first week of November 2014. The plot size was $20 \mathrm{~m}^{2}(5 \mathrm{~m} \mathrm{X} 4 \mathrm{~m})$. The field was fertilized with urea (as per treatment), triple super phosphate, muriate of potash, zypsum, and boric acid at the recommended doses. One third of urea and all other fertilizers were applied during final land preparation. As per treatment, the rest of two-thirds of urea were top dressed in two equal splits, one of the crown root initiation stage (50 days after sowing-DAS) and the other at panicle initiation stage (80 DAS).

Experimental crop was irrigated for three times at intervals of 20, 45 and 70 DAS. All necessary management practices were carried out as per standard recommendation for maize crop. All vegetative and reproductive parameters were recorded. Plant height, plant girth, total number of leaves plant ${ }^{-1}$, effective leaves plant ${ }^{-1}$, non-effective leaves plant ${ }^{-1}$, total roots plant ${ }^{-1}$, straw weight plant ${ }^{-1}$, straw yield $\left(\mathrm{t} \mathrm{ha}^{-1}\right)$ were measured during vegetative period. Data on different yield parameters such as cob length, cob grain free and cob girth were measured with measuring scale, and counted the grain line $\mathrm{cob}^{-1}$, grain number $\operatorname{line}^{-1}$, total grain $\mathrm{cob}^{-1}$, and finally grain weight $\mathrm{cob}^{-1}, 1000$ grain weight, grains yield $\left(\mathrm{t} \mathrm{ha}^{-1}\right)$, straw yield $\left(\mathrm{t} \mathrm{ha}^{-1}\right)$, and biological yield $\left(\mathrm{t} \mathrm{ha}^{-1}\right)$ were weighed with electrical balance. The crop was harvested manually at full maturity. The harvested crop of the plot was bundled separately, tagged properly and bring to the clean threshing floor. The seeds and straw weight for each plot were recorded after sun drying and 
weighed. Cobs were de-husked, dried, shelled and weighed with electric balance. The data were analyzed statistically using the analysis of variance (ANOVA) technique with the help of MSTAT-C (Gomez \& Gomez, 1984) and Microsoft excel program, and mean differences were adjusted by Duncan's Multiple Range Test (DMRT).

\section{Results and Discussion}

3.1 Effect of Nitrogen fertilization of various growths attributes of corn

Nitrogen treatments significantly influenced the plant height in BARI hybrid maize-7 and BARI hybrid maize-9. Maximum plant height $(269.3 \mathrm{~cm})$ was achieved withN $\mathrm{N}_{3}\left(345 \mathrm{~kg} \mathrm{~N} \mathrm{ha}^{-1}\right)$, which was significantly different from other two treatments. While, the lowest plant height $(235.7 \mathrm{~cm})$ was recorded in control treatment without nitrogen (Table 1). Jat et al. (2009) reported that the plant height of sweet corn was significantly improved with the increase in rate of nitrogen fertilizer from 50 per cent $\left(60 \mathrm{~kg} \mathrm{~N}^{-1}\right)$ to 100 percent of the recommended doses of fertilizers (RDF) (120 kg N ha ${ }^{-1}$ ) and application of 100 per cent RDF significantly produced more dry matter (137.95 $\mathrm{g} \mathrm{plant}^{-1}$ ) than 75 and 50 per cent RDF. Sahoo \& Panda (2009) reported that plant height increased gradually with increasing the nitrogen levels. Similarly, Singh (2011) revealed that $150 \mathrm{~kg} \mathrm{ha}^{-1} \mathrm{~N}$ produced the highest plant height in baby corn during summer while Thakur \& Sharma (2009) reported that maximum plant height can be achieved at $200 \mathrm{~kg}$ $\mathrm{ha}^{-1} \mathrm{~N}$ for the same plant. This thing justifies that maximum amount of nitrogen for same crop varies with the study area. Like plant growth, plant girth also increased gradually with increasing nitrogen treatments. Nitrogen levels showed significant positive effect on plant girth in BARI hybrid maize7 and BARI hybrid maize- 9 . The highest plant girth $(12.00 \mathrm{~cm})$ was recorded in BARI hybrid-7 from the treatment containing $345 \mathrm{~kg} / \mathrm{ha}$ nitrogen levels while the smallest plant girth (7.33) was in observed BARI hybrid-9 with $115 \mathrm{~kg} / \mathrm{ha}$ nitrogen, which was statistically different from $345 \mathrm{~kg} / \mathrm{ha}$ nitrogen levels (Table 1).

Table 1 Effect of nitrogen on the growth and growth performance of BARI hybrid maize-7 and BARI hybrid maize-9
Result of present study are contradictory to the findings of Kumar (2008) and Ummed et al. (2012), those who achieved maximum plant girth by application of $120 \mathrm{~kg} / \mathrm{ha}$ nitrogen in the form of urea with combined $30 \mathrm{~kg} / \mathrm{ha}$ nitrogen through poultry manure. Similarly Suryavanshi et al. (2008) also achieved highest plant girth on the application of $150 \mathrm{~kg} \mathrm{~N} \mathrm{ha}^{-1}$ and this was significantly differ from the treatment have 50 and $100 \mathrm{~kg}$ nitrogen $\mathrm{ha}^{-1}$ in case of traditional maize variety. Total leaves plant ${ }^{-1}$ of BARI hybrid maize-9 was significantly influenced by the treatments of nitrogen (Table 1). The highest total leaves plant- $^{-1}$ (14.00) was produced in BARI hybrid maize-9 at $345 \mathrm{~kg} \mathrm{~N}^{-1}$ while the lowest (12.00) was obtained at controlled treatment $\left(\mathrm{N}_{0}\right)$ of BARI hybrid maize-7. Total leaves plant ${ }^{-1}$ gradually increased with increasing nitrogen levels but there was no significant difference among the various treatments in case of BARI hybrid maize-7. Thakur et al. (2007) reported that growth parameters of inbred maize viz., total leaf, leaf area and the accumulation of dry matter/plant were improved by the increase nitrogen up to $150 \mathrm{~kg} \mathrm{~N}^{-}$ ${ }^{1}$.Nitrogen positively affected the effective leaves plant $^{-1}$ in both hybrids of maize (Table 1). The highest effective leaves plant $^{-1}$ (12.50 and 13.00) were observed with $\mathrm{N}_{3}$ treatment in BARI hybrid maize-7 and BARI hybrid maize-9, respectively and the lowest effective leaves plant ${ }^{-1}$ (9.63) were observed with $\mathrm{N}_{0}$ treatment in BARI hybrid maize-7. BARI hybrid maize-9 produced higher number of effective leaves as compared to BARI hybrid maize-7 in all levels nitrogen treatments. Bindhani et al. (2007) stated that effective leaves gradually increased with increasing nitrogen levels in baby corn.

The number of non-effective leaves plant ${ }^{-1}$ was influenced by the action of nitrogen in BARI hybrid maize-7 and BARI hybrid maize-9. The effect of nitrogen on the non-effective tillers was opposite to as found in effective tillers (Table 2). The highest non-effective leaves plant ${ }^{-1}$ (2.67 and 1.67) was produced in $\mathrm{N}_{0}$ and the lowest non-effective leaves (1.00 and 1.00) was produced $\mathrm{N}_{3}$ treatment, which were statistically differed from other nitrogen levels.

\begin{tabular}{|c|c|c|c|c|c|c|c|c|}
\hline \multirow[t]{2}{*}{ Treatments } & \multicolumn{2}{|c|}{ Plant height $(\mathrm{cm})$} & \multicolumn{2}{|c|}{ Plant girth $(\mathrm{cm})$} & \multicolumn{2}{|c|}{ Total leaves plant $^{-1}$} & \multicolumn{2}{|c|}{$\begin{array}{c}\text { Effective leaves } \\
\text { plant }^{-1}\end{array}$} \\
\hline & $\begin{array}{c}\text { BARI } \\
\text { hybrid } \\
\text { maize-7 }\end{array}$ & $\begin{array}{c}\text { BARI } \\
\text { hybrid } \\
\text { maize-9 }\end{array}$ & $\begin{array}{c}\text { BARI } \\
\text { hybrid } \\
\text { maize-7 }\end{array}$ & $\begin{array}{c}\text { BARI } \\
\text { hybrid } \\
\text { maize-9 }\end{array}$ & $\begin{array}{r}\text { BARI } \\
\text { hybrid } \\
\text { maize-7 } \\
\end{array}$ & $\begin{array}{c}\text { BARI } \\
\text { hybrid } \\
\text { maize-9 }\end{array}$ & $\begin{array}{c}\text { BARI } \\
\text { hybrid } \\
\text { maize-7 } \\
\end{array}$ & $\begin{array}{c}\text { BARI } \\
\text { hybrid } \\
\text { maize-9 }\end{array}$ \\
\hline $\mathrm{N}_{0}$ & $235.7^{\mathrm{d}}$ & $236.3^{\mathrm{d}}$ & $8.17^{\mathrm{bc}}$ & $7.50^{\mathrm{de}}$ & $12.00^{\mathrm{b}}$ & $12.30^{\mathrm{b}}$ & $9.63^{\mathrm{d}}$ & $10.93^{\mathrm{c}}$ \\
\hline $\mathrm{N}_{1}$ & $245.3 b^{c}$ & $246.3^{\mathrm{bc}}$ & $7.67^{\text {cde }}$ & $7.33^{\mathrm{e}}$ & $12.67^{\mathrm{b}}$ & $12.53^{\mathrm{b}}$ & $11.33^{\mathrm{ab}}$ & $11.33^{\mathrm{ab}}$ \\
\hline $\mathrm{N}_{2}$ & $249.0^{\mathrm{b}}$ & $256.3^{\mathrm{b}}$ & $8.00^{\text {bcd }}$ & $7.83^{\text {cde }}$ & $12.67^{\mathrm{b}}$ & $13.00^{\mathrm{b}}$ & $11.67^{\mathrm{ab}}$ & $12.00^{\mathrm{a}}$ \\
\hline $\mathrm{N}_{3}$ & $267.7^{\mathrm{a}}$ & $269.3^{\mathrm{a}}$ & $12.00^{\mathrm{a}}$ & $8.50^{\mathrm{b}}$ & $13.50^{\mathrm{ab}}$ & $14.00^{\mathrm{a}}$ & $12.50^{\mathrm{a}}$ & $13.00^{\mathrm{a}}$ \\
\hline $\operatorname{LSD}(0.05)$ & \multicolumn{2}{|c|}{14.74} & \multicolumn{2}{|c|}{0.59} & \multicolumn{2}{|c|}{0.98} & \multicolumn{2}{|c|}{1.51} \\
\hline $\mathrm{CV}(\%)$ & \multicolumn{2}{|c|}{3.32} & \multicolumn{2}{|c|}{4.04} & \multicolumn{2}{|c|}{4.42} & \multicolumn{2}{|c|}{8.63} \\
\hline
\end{tabular}

Results given in table are the mean of three replications, in a column figures having common letters(s) do not differ significant as per $D M R T$ 
Table 2 Effect of nitrogen on the growth and growth performance of BARI hybrid maize-7 and BARI hybrid maize-9

\begin{tabular}{|c|c|c|c|c|c|c|}
\hline \multirow[b]{2}{*}{ Treatments } & \multicolumn{2}{|c|}{ Non-effective leaves plant ${ }^{-1}$ ) } & \multicolumn{2}{|c|}{ Total roots plant ${ }^{-1}$} & \multicolumn{2}{|c|}{ Straw weight plant ${ }^{-1}$} \\
\hline & $\begin{array}{l}\text { BARI hybrid } \\
\text { maize-7 }\end{array}$ & $\begin{array}{c}\text { BARI hybrid } \\
\text { maize- } 9\end{array}$ & $\begin{array}{c}\text { BARI hybrid } \\
\text { maize-7 }\end{array}$ & $\begin{array}{c}\text { BARI hybrid } \\
\text { maize- } 9\end{array}$ & $\begin{array}{c}\text { BARI hybrid } \\
\text { maize-7 }\end{array}$ & $\begin{array}{c}\text { BARI hybrid } \\
\text { maize- } 9\end{array}$ \\
\hline $\mathbf{N}_{\mathbf{0}}$ & $2.67^{\mathrm{a}}$ & $1.47^{\mathrm{bc}}$ & $41.33^{\mathrm{b}}$ & $41.67^{\mathrm{b}}$ & $849.3^{\mathrm{e}}$ & $835.0^{\mathrm{e}}$ \\
\hline $\mathbf{N}_{1}$ & $1.33^{\mathrm{c}}$ & $1.33^{\mathrm{c}}$ & $40.00^{\mathrm{b}}$ & $40.67^{\mathrm{b}}$ & $1010^{\mathrm{d}}$ & $1050^{\mathrm{d}}$ \\
\hline $\mathbf{N}_{2}$ & $1.17^{\mathrm{cd}}$ & $1.30^{\mathrm{cd}}$ & $41.33^{\mathrm{b}}$ & $46.00^{\mathrm{a}}$ & $1266^{\mathrm{c}}$ & $1396^{\mathrm{ab}}$ \\
\hline $\mathbf{N}_{3}$ & $10.37^{\mathrm{ab}}$ & $10.99^{\mathrm{a}}$ & $45.33^{\mathrm{a}}$ & $48.00^{\mathrm{a}}$ & $1346^{\mathrm{b}}$ & $1430^{\mathrm{a}}$ \\
\hline LSD (0.05) & \multicolumn{2}{|c|}{0.82} & \multicolumn{2}{|c|}{3.10} & \multicolumn{2}{|c|}{50.79} \\
\hline $\mathrm{CV}(\%)$ & \multicolumn{2}{|c|}{18.25} & \multicolumn{2}{|c|}{4.12} & \multicolumn{2}{|c|}{2.53} \\
\hline
\end{tabular}

Results given in table are the mean of three replications, in a column figures having common letters(s) do not differ significant as per $D M R T$

Table 3 Effect of nitrogen on the yield and yield attributed traits of BARI hybrid maize-7 and BARI hybrid maize-9

\begin{tabular}{|c|c|c|c|c|c|c|c|c|}
\hline \multirow[b]{2}{*}{ Treatments } & \multicolumn{2}{|c|}{ Cob length $(\mathrm{cm})$} & \multicolumn{2}{|c|}{ Grain free cob } & \multicolumn{2}{|c|}{ Cob girth $(\mathrm{cm})$} & \multicolumn{2}{|c|}{ Grain line cob $^{-1}$} \\
\hline & $\begin{array}{c}\text { BARI } \\
\text { hybrid } \\
\text { maize-7 }\end{array}$ & $\begin{array}{c}\text { BARI } \\
\text { hybrid } \\
\text { maize-9 }\end{array}$ & $\begin{array}{c}\text { BARI } \\
\text { hybrid } \\
\text { maize-7 }\end{array}$ & $\begin{array}{c}\text { BARI } \\
\text { hybrid } \\
\text { maize-9 }\end{array}$ & $\begin{array}{c}\text { BARI } \\
\text { hybrid } \\
\text { maize-7 }\end{array}$ & $\begin{array}{c}\text { BARI } \\
\text { hybrid } \\
\text { maize-9 }\end{array}$ & $\begin{array}{c}\text { BARI } \\
\text { hybrid } \\
\text { maize-7 }\end{array}$ & $\begin{array}{c}\text { BARI } \\
\text { hybrid } \\
\text { maize-9 }\end{array}$ \\
\hline $\mathbf{N}_{\mathbf{0}}$ & $23.00^{\mathrm{c}}$ & $24.00^{\mathrm{bc}}$ & $1.67^{\mathrm{ab}}$ & $2.33^{\mathrm{a}}$ & $13.83^{\mathrm{b}}$ & $14.33^{\mathrm{b}}$ & $12.33^{\mathrm{c}}$ & $13.00^{\mathrm{bc}}$ \\
\hline $\mathbf{N}_{1}$ & $25.33^{\mathrm{b}}$ & $26.00^{\mathrm{b}}$ & $1.33^{\mathrm{ab}}$ & $1.78^{\mathrm{ab}}$ & $15.00^{\mathrm{a}}$ & $15.00^{\mathrm{a}}$ & $13.33^{\mathrm{abc}}$ & $13.67^{\mathrm{ab}}$ \\
\hline $\mathbf{N}_{2}$ & $27.00^{\mathrm{ab}}$ & $27.13^{\mathrm{ab}}$ & $0.67^{\mathrm{b}}$ & $1.00^{\mathrm{b}}$ & $15.33^{\mathrm{a}}$ & $15.33^{\mathrm{a}}$ & $13.67^{\mathrm{ab}}$ & $13.67^{\mathrm{ab}}$ \\
\hline $\mathbf{N}_{3}$ & $27.79^{\mathrm{a}}$ & $28.33^{\mathrm{a}}$ & $1.33^{\mathrm{ab}}$ & $1.63^{\mathrm{ab}}$ & $15.80^{\mathrm{a}}$ & $15.97^{\mathrm{a}}$ & $14.33^{\mathrm{a}}$ & $15.03^{\mathrm{a}}$ \\
\hline LSD (0.05) & \multicolumn{2}{|c|}{2.30} & \multicolumn{2}{|c|}{1.22} & \multicolumn{2}{|c|}{1.09} & \multicolumn{2}{|c|}{1.05} \\
\hline $\mathrm{CV}(\%)$ & \multicolumn{2}{|c|}{5.09} & \multicolumn{2}{|c|}{5.20} & \multicolumn{2}{|c|}{4.07} & \multicolumn{2}{|c|}{4.05} \\
\hline
\end{tabular}

Results given in table are the mean of three replications, in a column figures having common letters(s) do not differ significant as per $D M R T$

These results are in agreement with the findings of Nath et al. (2009) who observed that dry leaves gradually decreased with increasing nitrogen in maize. Tohidi et al. (2012) recorded maximum none effective leaves of maize crop with $150 \mathrm{~kg} \mathrm{~N}$ ha $^{-1}$. BARI hybrid maize-9 produced less non-effective leaves than in BARI hybrid maize-7. Nitrogen significantly influenced the total roots plant ${ }^{-1}$ BARI hybrid maize- 7 and BARI hybrid maize-9 (Table 2). The highest number of roots (48.00) was reported in BARI hybrid maize-9 with $\mathrm{N}_{3}$ treatment while the lowest roots (40.00) were in $\mathrm{N}_{1}$ treatment for both the varieties. This result might probably be due to more nitrogen enhanced more nutrients uptake especially nitrogen, which boosted more root production. Bruns \& Abbas (2005) stated that application of full amounts of $\mathrm{N}$ fertilizer prior to sowing may result in better root development over carrying out $\mathrm{N}$ split applications. The straw weight plant $^{-1}$ was remarkably increased with the increasing nitrogen levels in both varieties (Table 2). BARI hybrid maize-9 produced the highest straw weight plant $^{-1}(1430.0 \mathrm{~g})$ in the treatment of $\mathrm{N}_{3}$ while the lowest in $\mathrm{N}_{0}$ treatment. Enhancement of nitrogen application augmented more vegetative growth resulting more dry matter production. Kumar (2009) observed that successive increasing of nitrogen rate from 0 to $120 \mathrm{~kg} / \mathrm{ha}$ remarkably increased dry weight plant $^{-1}$ in popcorn. The most efficient time of $\mathrm{N}$ application in maize crop at vegetative growth stage
(V6) as reported by Wells \& Blitzer (1984), and Wells et al. (2012).

3.2 Effect of Nitrogen fertilization of various yields attributes of corn

Like various growth attributes, various yield parameters also affect by the application of nitrogen fertilizers. Among this, cob length was significantly influenced by nitrogen treatments in BARI hybrid maize-7 and BARI hybrid maize-9, and longest cob length was observed in BARI hybrid maize-9 (Table 3). The maximum length for cob $(28.33 \mathrm{~cm})$ was achieved by application $\mathrm{N}_{3}$ treatment, which was statistically similar with $\mathrm{N}_{2}$ treatment. The lowest cob length $(23.00 \mathrm{~cm})$ was found in treatment $\mathrm{N}_{0}$, which was statistically differs from other two treatments in both varieties. Thakur \& Sharma (2009) observed that the maximum cob length with application of $200 \mathrm{~kg} \mathrm{~N} \mathrm{ha}^{-1}$ as compared to $100 \mathrm{~kg} \mathrm{~N} \mathrm{ha}^{-1}$. In contrary to this, Pandey et al. (2010) did not found any positive variation in the length of baby corn with increasing of nitrogen rate from 60 to $120 \mathrm{~kg} \mathrm{Nha}^{-1}$. The cob grain free length showed insignificant variations among the nitrogen treatments in BARI hybrid maize-7 and BARI hybrid maize-9 (Table 3). The highest grain free cob length $(1.67 \mathrm{~cm}$ and $2.33 \mathrm{~cm})$ found with $\mathrm{N}_{0}$ and the lowest $(0.67 \mathrm{~cm}$ and $1.33 \mathrm{~cm})$ obtained $\mathrm{N}_{2}$ treatment 
in both varieties of BARI hybrid maize-7 and BARI hybrid maize-9, respectively. The cob grain free values decreased with the increasing of nitrogen levels up to $\mathrm{N}_{2}$ treatment and thereafter increased in both varieties. The increased cob grain free length might be due to increased nitrogen levels enhanced more grains in cob which reduced the length of free cob grain space. Similar results were also reported by Kar et al. (2006) in maize crop. Cob girth of BARI hybrid maize-7 and BARI hybrid maize-9 was significantly influenced by different levels of nitrogen (Table 3). The cob girth increased with increasing nitrogen levels. BARI hybrid maize-9 produced the highest cob girth $(16.67 \mathrm{~cm})$ in $\mathrm{N}_{3}$ treatments, which haven't significant difference with $\mathrm{N}_{2}$ and $\mathrm{N}_{1}$ treatments. The lowest cob girth was obtained where no nitrogen $\left(\mathrm{N}_{0}\right)$ were used. The increment of cob girth might be due to the supply of sufficient nitrogen. Singh et al. (2010a) observed that adding of $180 \mathrm{~kg}$ of N ha ${ }^{-1}$ compared to $60 \mathrm{~kg}$ of $\mathrm{N} \mathrm{ha}^{-1}$ positively improved cob girth in baby corn. Similarly, Raja (2011) observed that the increase in nitrogen rates application from 0 to $120 \mathrm{~kg} \mathrm{~N} / \mathrm{ha}$ positively improved the cob girth of sweet corn. The influence of nitrogen levels was significant on the grain line $\mathrm{cob}^{-1}$ in BARI hybrid maize-7 and BARI hybrid maize-9 (Table 3). In both varieties, the highest value (14.33) was obtained from $\mathrm{N}_{3}$ treatment, which was statistically not different from the rest two nitrogen levels $\left(\mathrm{N}_{2}\right.$ and $\left.\mathrm{N}_{1}\right)$. The lowest grain line $\operatorname{cob}^{-1}$ (12.33 and 13.00) was found in BARI hybrid maize-7 and BARI hybrid maize-9, respectively at $N_{0}$ treatment. The grain line values gradually increased with increasing nitrogen levels. It might be due to the application of more nitrogen improved crop growth which ultimately increased grains line $\mathrm{cob}^{-1}$. Kang et al. (2005) observed that application of $100 \mathrm{~kg} \mathrm{~N} \mathrm{ha}^{-1}$ was the optimum to achieve the optimum grain line $\mathrm{cob}^{-1}$ and yield of sweet corn.

The effect of different nitrogen levels was statistically important for the total grains $\mathrm{cob}^{-1}$ of BARI hybrid maize-7 and BARI hybrid maize-9 (Table 4). The highest total grains $\operatorname{cob}^{-1}$ were obtained from treatments of $\mathrm{N}_{2}$ and $\mathrm{N}_{3}$, while the lowest total grain $\mathrm{cob}^{-1}$ was obtained from $\mathrm{N}_{0}$ treatment in both the varieties. Total grains $\mathrm{cob}^{-1}$ were increased with the increasing nitrogen levels. The optimum grains $\operatorname{cob}^{-1}$ was observed with application of $120 \mathrm{~kg} \mathrm{~N}^{-1}$ than that of with 60 and $90 \mathrm{~kg} \mathrm{~N} \mathrm{ha}^{-1}$ in baby corn (Pandey et al., 2010). Adding of $120 \mathrm{~kg} \mathrm{~N} \mathrm{ha}^{-1}$ in baby corn resulted in the maximum grains $\operatorname{cob}^{-1}$ and the yield of corn as well, which was 28.6, 52.2 and $178.7 \%$ higher than that of 80,40 and $0 \mathrm{~kg} \mathrm{~N} \mathrm{ha}^{-1}$, respectively (Bindhani et al.,2007). It was observed that the application of $180 \mathrm{~kg} \mathrm{~N} \mathrm{ha}^{-1}$ was positive improves in grains $\mathrm{cob}^{-1}$ and grain yield as compared to $60 \mathrm{~kg} \mathrm{~N} \mathrm{ha}^{-1}$ (Singh et al., 2010b). Nitrogen treatments had significant effect on grain number line $^{-1}$ of BARI hybrid maize-7 and BARI hybrid maize-9 (Table 4). The maximum grain number $\operatorname{line}^{-1}$ (56.00) was counted at $\mathrm{N}_{2}$, which was statistically similar with $\mathrm{N}_{3}$, while the lowest grain number line ${ }^{-1}$ was obtained at $\mathrm{N}_{0}$. Adding of $120 \mathrm{~kg} \mathrm{~N} \mathrm{ha}^{-1}$ resulted in the optimum grain number/line of baby corn without husk compared to other rates of $\mathrm{N}$ treatments (Sahoo \& Panda, 2007). Increasing of nitrogen levels increased the grain number line $e^{-1}$ up to $\mathrm{N}_{2}$ treatment and afterward it declined.

It was conformed that increasing nitrogen level increased yield in an optimum level. The effect of different levels of nitrogen was significant on 1000-grain weight in both the varieties BARI hybrid maize-7 and BARI hybrid maize-9 (Table 4). Significantly highest 1000 -grain weight $(273.4 \mathrm{~g})$ was recorded from $\mathrm{N}_{3}$ in BARI hybrid maize-9 among all the nitrogen levels which was statistically similar with BARI hybrid maize-7. It might probably be due to use of increasing levels of nitrogen. The lowest 1000 -grain weight $(244.8 \mathrm{~g})$ was counted with no nitrogen $\left(\mathrm{N}_{0}\right)$ treatment in BARI hybrid maize-7, which was statistically identical with BARI hybrid maize- 9 with the same nitrogen level. Thakur et al. (2007) observed that the maximum 1000-grain weight of baby corn/plant with application of 200 $\mathrm{kg} \mathrm{N} \mathrm{ha}{ }^{-1}$ as compared to other nitrogen treatments on Alfisols of Bajura, Kullu valley, Himachal Pradesh, India. The highest length, weight of ear and number of ears per plant of baby corn were found at $120 \mathrm{~kg} \mathrm{~N} \mathrm{ha}^{-1}$ (Sahoo \& Panda, 2009). The cob length was significantly influenced by nitrogen treatments in BARI hybrid maize-7 and longer cob length was observed in BARI hybrid maize-9 (Table 4). Maximum grain weight $\operatorname{cob}^{-1}$ $(204.0 \mathrm{~g})$ was observed with $\mathrm{N}_{3}$ treatment in BARI hybrid maize-9, which was statistically similar with BARI hybrid maize-7 under similar treatment condition. The minimum grain weight $\operatorname{cob}^{-1}(127.3 \mathrm{~g})$ was counted without nitrogen fertilization in BARI hybrid maize-7, which was statistically similar with BARI hybrid maize- 9 at $\mathrm{N}_{0}$ treatment. Grain weight $\operatorname{cob}^{-1}$ was increased with the increasing nitrogen levels. It was conformed that nitrogen supply increased grain weight $\mathrm{cob}^{-1}$ in different studies. Mullins et al. (2009) found that 112 $\mathrm{kg} \mathrm{N} \mathrm{ha}{ }^{-1}$ was sufficient for achieving the optimum grain weight $\mathrm{cob}^{-1}$ in sweet corn. The optimum weight of green cobs was produced by Akthar\& Silva (2009)with $150 \mathrm{~kg} \mathrm{~N} \mathrm{ha}^{-1}$, Sahoo \& Mahapatra (2014) with $120 \mathrm{~kg} \mathrm{~N} \mathrm{ha}^{-1}$.

Nitrogen treatment showed positive effect on grain yield in BARI maize-7 and BARI hybrid maize-9 (Table 5). The highest grain yield $\left(10.87 \mathrm{t} \mathrm{ha}^{-1}\right)$ was produced with $\mathrm{N}_{3}$ treatment in BARI hybrid maize-9, which was statistically similar with $\mathrm{N}_{2}$ treatment and statistically the lowest grain yield $\left(6.19 \mathrm{t} \mathrm{ha}^{-1}\right)$ was recorded $\mathrm{inN}_{0}$ treatment. Application of more nitrogen enhanced plant growth and yield contributing traits which might probably increased grain yield of hybrid maize. Sahoo \& Mahapatra (2014) found that improved rates of nitrogen application from 60 to $180 \mathrm{~kg} \mathrm{ha}^{-1}$ improved the yield of grain from 8.88 to $10.53 \mathrm{tha}^{-1}$, respectively. Adding of $160 \mathrm{~kg} \mathrm{~N} \mathrm{ha}^{-1}$ achieved maximum productivity in corn (Shanti et al., 2007; Muniswamy et al., 2007). Gormus et al. (2016) found that combination of $180 \mathrm{~kg} \mathrm{ha}^{-1}$ nitrogen and $100 \mathrm{~kg} \mathrm{ha}^{-1}$ potassium are appropriate to achieve the maximum yield of cotton crop. The maximum grain yield of fine rice produced with application of $150 \mathrm{~kg} \mathrm{ha}^{-1}$ (Rashid et al., 2016). 
Table 4 Effect of nitrogen on the yield and yield attributed traits of BARI hybrid maize-7 and BARI hybrid maize-9

\begin{tabular}{|c|c|c|c|c|c|c|c|c|}
\hline \multirow[b]{2}{*}{ Treatments } & \multicolumn{2}{|c|}{ Total grain cob $^{-1}$} & \multicolumn{2}{|c|}{ Grain number line $\mathrm{e}^{-1}$} & \multicolumn{2}{|c|}{ 1000-grains weight (g) } & \multicolumn{2}{|c|}{ Grain weight cob $^{-1}(g)$} \\
\hline & $\begin{array}{c}\text { BARI } \\
\text { hybrid } \\
\text { maize-7 }\end{array}$ & $\begin{array}{c}\text { BARI } \\
\text { hybrid } \\
\text { maize-9 }\end{array}$ & $\begin{array}{c}\text { BARI } \\
\text { hybrid } \\
\text { maize-7 }\end{array}$ & $\begin{array}{c}\text { BARI } \\
\text { hybrid } \\
\text { maize-9 }\end{array}$ & $\begin{array}{c}\text { BARI } \\
\text { hybrid } \\
\text { maize-7 }\end{array}$ & $\begin{array}{c}\text { BARI } \\
\text { hybrid } \\
\text { maize-9 }\end{array}$ & $\begin{array}{c}\text { BARI } \\
\text { hybrid } \\
\text { maize-7 }\end{array}$ & $\begin{array}{l}\text { BARI } \\
\text { hybrid } \\
\text { maize-9 }\end{array}$ \\
\hline $\mathbf{N}_{0}$ & $515.3^{\mathrm{c}}$ & $541.3^{\mathrm{c}}$ & $44.67^{\mathrm{c}}$ & $45.00^{\mathrm{c}}$ & $244.8^{\mathrm{d}}$ & $252.1^{\mathrm{d}}$ & $127.3^{\mathrm{d}}$ & $131.7^{\mathrm{d}}$ \\
\hline $\mathrm{N}_{1}$ & $671.00^{\mathrm{b}}$ & $674.30^{\mathrm{b}}$ & $49.33 b^{c}$ & $50.33^{\mathrm{bc}}$ & $260.7^{\mathrm{c}}$ & $259.0^{c}$ & $172.0^{\mathrm{c}}$ & $171.3^{\mathrm{c}}$ \\
\hline $\mathbf{N}_{2}$ & $744.00^{\mathrm{a}}$ & $741.70^{\mathrm{a}}$ & $54.67^{\mathrm{a}}$ & $56.00^{\mathrm{a}}$ & $262.4^{\mathrm{bc}}$ & $263.2^{\mathrm{bc}}$ & $194.3^{\mathrm{b}}$ & $195.7^{\mathrm{b}}$ \\
\hline $\mathbf{N}_{3}$ & $742.70^{\mathrm{a}}$ & $746.70^{\mathrm{a}}$ & $50.00^{\mathrm{b}}$ & $53.00^{\mathrm{ab}}$ & $272.6^{\mathrm{a}}$ & $273.4^{\mathrm{a}}$ & $202.7^{\mathrm{a}}$ & $204.0^{\mathrm{a}}$ \\
\hline LSD (0.05) & \multicolumn{2}{|c|}{48.25} & \multicolumn{2}{|c|}{4.40} & \multicolumn{2}{|c|}{11.40} & \multicolumn{2}{|c|}{4.46} \\
\hline $\mathrm{CV}(\%)$ & \multicolumn{2}{|c|}{4.10} & \multicolumn{2}{|c|}{5.00} & \multicolumn{2}{|c|}{2.50} & \multicolumn{2}{|c|}{1.46} \\
\hline
\end{tabular}

Results given in table are the mean of three replicates, in a column figures having common letters(s) do not differ significant as per $D M R T$

Table 5 Effect of nitrogen on the yield and yield attributed traits of BARI hybrid maize- 7 and BARI hybrid maize- 9

\begin{tabular}{|c|c|c|c|c|c|c|}
\hline \multirow[b]{2}{*}{ Treatments } & \multicolumn{2}{|c|}{ Grain yield $\left(t h^{-1}\right)$} & \multicolumn{2}{|c|}{ Straw yield $\left(\mathbf{t ~ h a} \mathbf{h}^{-1}\right)$} & \multicolumn{2}{|c|}{ Biological yield $\left(\mathrm{t} \mathrm{ha}^{-1}\right)$} \\
\hline & $\begin{array}{l}\text { BARI hybrid } \\
\text { maize-7 }\end{array}$ & $\begin{array}{c}\text { BARI hybrid } \\
\text { maize- } 9\end{array}$ & $\begin{array}{c}\text { BARI hybrid } \\
\text { maize-7 }\end{array}$ & $\begin{array}{c}\text { BARI hybrid } \\
\text { maize- } 9\end{array}$ & $\begin{array}{l}\text { BARI hybrid } \\
\text { maize-7 }\end{array}$ & $\begin{array}{c}\text { BARI hybrid } \\
\text { maize- } 9\end{array}$ \\
\hline $\mathbf{N}_{0}$ & $6.19^{c}$ & $6.22^{\mathrm{c}}$ & $42.00^{\mathrm{d}}$ & $41.53^{\mathrm{d}}$ & $48.22^{\mathrm{d}}$ & $47.75^{\mathrm{d}}$ \\
\hline $\mathbf{N}_{1}$ & $8.12^{\mathrm{b}}$ & $8.94^{\mathrm{b}}$ & $53.55^{\mathrm{c}}$ & $54.95^{\mathrm{c}}$ & $63.40^{\mathrm{c}}$ & $63.59^{\mathrm{c}}$ \\
\hline $\mathbf{N}_{2}$ & $9.98^{\mathrm{b}}$ & $10.38^{\mathrm{ab}}$ & $62.49^{\mathrm{b}}$ & $64.28^{\mathrm{b}}$ & $72.47^{\mathrm{b}}$ & $74.00^{\mathrm{b}}$ \\
\hline $\mathbf{N}_{3}$ & $10.37^{\mathrm{ab}}$ & $10.99^{\mathrm{a}}$ & $66.51^{\mathrm{a}}$ & $66.77^{\mathrm{a}}$ & $77.29^{\mathrm{a}}$ & $77.66^{\mathrm{a}}$ \\
\hline LSD (0.05) & \multicolumn{2}{|c|}{1.17} & \multicolumn{2}{|c|}{1.98} & \multicolumn{2}{|c|}{1.85} \\
\hline CV $(\%)$ & \multicolumn{2}{|c|}{7.43} & \multicolumn{2}{|c|}{2.00} & \multicolumn{2}{|c|}{1.61} \\
\hline
\end{tabular}

Results given in table are the mean of three replicates, in a column figures having common letters(s) do not differ significant as per $D M R T$

To achieve the optimum yield and $\mathrm{N}$ use efficiencies of wheat might be applying $172.5 \mathrm{~N} \mathrm{kgha}^{-1}$ with sprays $200 \mathrm{ml} \mathrm{L}^{-}$ ${ }^{1}$ ascobien (Gharib et al., 2016). Nitrogen significantly influenced the straw yield in BARI hybrid maize-7 and BARI hybrid maize-9 (Table 5). The highest straw yields (66.51 and $66.77 \mathrm{t} \mathrm{ha}^{-1}$ ) were obtained with $\mathrm{N}_{3}$ treatment and the lowest straw yields (42.00 and $41.53 \mathrm{tha}^{-1}$ ) with $\mathrm{N}_{0}$ treatment in BARI hybrid maize-7 and BARI hybrid maize-9, respectively. A significant improvement in the baby corn was increased with increasing the application of nitrogen rates from 100 to $200 \mathrm{~kg}$ $\mathrm{ha}^{-1}$.The effect of different level of nitrogen on biological yield was significant in BARI hybrid maize-7 and BARI hybrid maize-9 and the highest biological yield was obtained from BARI hybrid maize-9 (Table 5).The maximum biological yield $\left(77.66 \mathrm{tha}^{-1}\right.$ ) was obtained with $\mathrm{N}_{3}$ and no statistical variation was recorded with BARI hybrid maize-7. The lowest straw yield (47.75 $\mathrm{t} \mathrm{ha}^{-1}$ ) was counted in BARI hybrid maize-9 with $\mathrm{N}_{0}$ and statistically differed from other treatments but similar with BARI hybrid maize-7. It was reported that continuous increasing in nitrogen rates from 80 to $120 \mathrm{~kg} \mathrm{ha}^{-1}$ achieved markedly maximum of biological yield from 200.0 and $222.4 \%$ over control, respectively (Kumar,2009). Maximum biological yield of sweet corn was achieved with $150 \mathrm{~kg} \mathrm{~N}$ ha ${ }^{1}$ (Rao \& Padmaja, 2014).

\section{Conclusion}

Nitrogen levels had pronounced effect on growth and grain yield of hybrid maize. Further, yield and yield traits gradually increased with increasing nitrogen levels from $0\left(\mathrm{~N}_{0}\right)$ to $345 \mathrm{~kg}$ $\mathrm{ha}^{-1}\left(\mathrm{~N}_{3}\right)$. Nitrogen application at $345 \mathrm{~kg}$ ha- ${ }^{1}$ produced the highest yield and yield traits, but in most of the cases it was statistically similar with $230 \mathrm{~kg}$ ha $1 \mathrm{~N}$. On the other hand, BARI hybrid maize- 9 performed better than BARI hybrid maize-7 in all levels of nitrogen treatments. Accordingly, it might be summarized that BARI hybrid maize- 9 could be cultivated by application of $230 \mathrm{~kg} \mathrm{~N} \mathrm{ha}^{-1}$ to achieve the optimum economic benefit.

\section{Conflict of interest}

Authors would hereby like to declare that there is no conflict of interests that could possibly arise.

\section{References}

Abd el-wahed MH, EL Sabagh A, Zayed A, Sanussi A, Saneoka A, Barutçular C (2015) Improving yield and water productivity of maize grown under deficit-irrigated in dry area conditions. Azarian Journal of Agriculture 2: 123-132. 
Agriculture Information Service (2017) Krishi Diary (In Bangla). Agriculture Information Service. Ministry of Agriculture, Government of the Peoples Republic of Bangladesh, Khamarbari, Dhaka-1215. p. 18.

Akbar M, Shakoor MS, Hussain A, Sarwar M (2008) Evaluation of maize 3 way crosses through genetic variability, broad-sense heritability, characters associate on and path analysis. Journal of Agricultural Research 46: 39-45.

Akthar M, Silva JA (2009) Agronomic traits and productivity of sweet corn affected by nitrogen and intercropping. Pakistan Journal of Soil Science 16: 49-52.

Barutçular C, Dizlek H, EL- Sabagh A, Sahin T, EL- Sabagh M, Islam MS (2016a) Nutritional quality of maize in response to drought stress during grain-filling stages in mediterranean climate condition. Journal of Experimental Biology and Agricultural Sciences 4: 644-652. DOI: 10.18006/2016.4 (Issue6).644.652.

Barutcular C, EL Sabagh A, Konuskan O, Saneoka H (2016b) evaluation of maize hybrids to terminal drought stress tolerance by defining drought indices Journal of Experimental Biology and $\begin{array}{llll}\text { Agricultural } & \text { Sciences } & 4 & \text { : }\end{array}$ http://dx.doi.org/10.18006/2016.

Bindhani A, Barik KC, Garnayak LM, Mahapatra PK (2007) Nitrogen management in baby corn (Zea mays). Indian Journal Agronomy 52: 135-138.

Blackmer AM, Pottker D, Cerrato ME, Webb J (2009) Correlations between soil nitrate concentrations in late spring and corn yields in Iowa. American Society of Agronomy 2:103-109. doi:10.2134/jpa1989.0103.

Bruns HA, Abbas HK (2005) Ultra-high plant populations and nitrogen fertility effects on corn in the Mississippi valley. Agronomy Journal 97: 1136-1140.doi:10.2134/ agronj2004.0295.

Bundy LG, Andraski TW, Ruark MD, Peterson AE (2011) Longterm continuous maize and nitrogen fertilizer effects on productivity and soil properties. Agronomy Journal 103: 13461351. doi:10.2134/agronj2011.0094.

Carpici EB, Celik N, Bayram G (2010) Yield and quality of forage maize as influenced by plant density and nitrogen rate. Turkish Journal of Field Crops 15: 128-132.

EL Sabagh A, Barutçular C, Islam MS (2017) Relationships between stomatal conductance and yield under deficit irrigation in maize (Zea mays L.). Journal of Experimental Biology and Agricultural Sciences 5:15-21. DOI 10.18006/2017.5 (1).014.021.

EL Sabagh A, Barutçular C, Saneoka H (2015) Assessment of drought tolerance maize hybrids at grain growth stage in Mediterranean area. International Journal of Biological,
Biomolecular, Agricultural, Food and Biotechnological Engineering 9: 962-965.

Evans LT (2008) Feeding the Ten Billion. Plants and population growth. Cambridge University Press, p.247.

FRG (2012) Fertilizer Recommendation Guide. Bangladesh Agricultural Research Council (BARC). Farmgate, Dhaka-1215.

Gasim DA, Battaglin WA, Aulenbach BT, Hooper RP (2011) Nitrogen Input to the Gulf of Mexico. Journal of Environment and Quality 30: 329-336. doi:10.2134/jeq2001.302329x.

Gharib H, Hafez E, EL Sabagh A (2016) Optimized potential of utilization efficiency and productivity in wheat by integrated chemical nitrogen fertilization and simulative compounds. Cercetari Agronomice in Moldova 2 : 5-20. doi:10.1515/cerce2016-0011.

Gomez KA Gomez AA (1984) Statistical Procedure of Agricultural Research. John Wiley and Sons, New York, USA. pp. 200-215.

Gormus O, EL Sabagh A, Islam MS (2016) Optimizing yield and fiber quality of cotton under Mediterranean environment: managing nitrogen and potassium nutrition. Journal of Experimental Biology and Agricultural Sciences 4 (Suppl.) 572580. DOI: http://dx.doi.org/10.18006/2016.4(5S).572.580.

Hopf N, Plesofsky-Vig N, Brambl R (1992) The heat shock response of pollen and other tissues of maize. Plant Molecular Biology 19 : 623-630. doi:10.1007/BF00026788.

Jat V, Tuse BP, Jawale SM, Shaikh AA, Dalavi ND (2009) Effect of fertilizer levels and dates of sowing on growth and yield of sweet corn (Zea mays saccharata). Journal Maharastra Agricultural University 34 : 109-111.

John GW, Schmitt MA (2007) Advisability of fall-applying nitrogen. Proceedings of the 2008 Wisconsin Fertilizer, Aglime and Pest Management Conference, held on the $15-17^{\text {th }}$ January, 2008 at University of Wisconsin, Madison, WI. pp. 90-96.

Jules YK, Park KY Moon HG, Lee SJ (2014) Effect of compost, rate and split application of nitrogen on growth and yield of sweet corn. Korea Agricultural Science 30 : 140-145.

Kang F, Breidy J, Stephan C, Rouphael J (2005) Evapotranspiration, yield and water use efficiency of drip irrigated corn in the Bekaa Valley of Lebanon. Agricultural Water Management 63 : 125-137. DOI: 10.1016/S0378-3774(03)00179-3.

Kar PP, Barik KC, Mahapatra PK, Garnayak LM, Rath BS, Bastia DK, Khanda CM (2006) Effect of planting geometry and nitrogen on yield, economics and nitrogen uptake of sweet corn (Zea mays). Indian Journal Agronomy $51:$ 43-45. 
Khan S, Awan IU, Baloch MS Khan EA, Khakwani AA, Hussain N (2013) Performance of maize varieties under irrigated conditions of DeraIsmailKhan. Gomal University Journal Research 29 :26-31.

Kumar A (2008) Productivity, economics and nitrogen- use efficiency of speciality corn (Zea mays) as influenced by planting density and nitrogen fertilization. Indian Journal of Agronomy 53: 306-309.

Kumar A (2009) Influence of varying plant population and nitrogen levels on growth, yield, economics and nitrogen use efficiency of popcorn (Zea mays evertasturt). Crop Research 37: 19-23.

Kumar D, Jhariya AN (2013) Nutritional, Medicinal and Economical importance of Corn: A Mini Review. Research Journal of Pharmaceutical Sciences $2: 7-8$.

McCullough DE, Giradin P, Mihajlovic M, Aguilera A, Tollenaar $\mathrm{M}$ (1994) Influence of $\mathrm{N}$ supply on development and dry matter accumulation of an old and new maize hybrid. Canadian Journal of Plant Science 74: 471-477.

Mullins CA, Straw RA, Pilt BJ, Onks DO, Reynolds J, Kirchner M (2009) Response of selected sweet corn cultivars to nitrogen fertilization. Horticulture Technology 9 : 32-35.

Muniswamy S, Gowda R, Prasad SR (2007) Effect of spacing and nitrogen levels on seed yield and quality of maize single cross hybrid PEHM-2. Mysore Journal Agricultural Science 41 : 186190.

Nath K, Nepalia V, Singh D (2009) Effect of integarated nutrient management on growth and yield of sweet corn (Zea mays L. ssp. saccharata). Annals Agricultural Research 30 : 73-76.

Omara RA, Kurtz LT (2009) Crop nitrogen requirement, utilization, and fertilization. In: Stevenson FJ (Ed.) Nitrogen in agricultural soils. Agronomy Monogram. 22, ASA and SSSA, Madison, WI. pp. 567-599.

Pandey AK, Prakash Ved, Mani VP, Singh RD (2010) Effect of rate of nitrogen and time of application on yield and economics of baby corn (Zea mays L.). Indian Journal of Agronomy 45 : 338343.

Raja V (2011) Effect of nitrogen and plant population on yield and quality of super sweet corn (Zea mays ). Indian Journal of Agronomy 46 : 246-249.

Rao KL, Padmaja M (2014) Nitrogen requirement of maize (Zea mays) types. Journal of Research in Andhra Pradesh Agricultural University 22: 151.

Rashid MH, Chowdhury K, EL Sabagh A, Barutçular C, Islam MS (2016) Effect of split application of nitrogen fertilizer on yield traits and vield of high vielding aromatic rice varieties in
Bangladesh. Agricultural Advances 5 : 368-374. doi: 10.14196/aa.v5i11.2334.

Sahoo SC, Mahapatra PK (2014) Response of sweet corn (Zea mays) to nitrogen levels and plant population. Indian Journal Agricultural Science 74 : 337-338.

Sahoo SC, Panda MM (2007) Fertilizer requirement of baby corn (Zea mays) in wet and winter seasons Indian Journal Agricultural Science 67 : 397-398.

Sahoo SC, Panda MM (2009) Effect of level of nitrogen and plant population on yield of baby corn (Zea mays). Indian Journal Agricultural Science 69 : 157-158.

Sawi J, Dhindwal AS Malik AS Poonia SR (2013) Effect of irrigation regime and nitrogen on winter maize under shallow water table condition. Journal of Water Management 1: 22-24.

Shanti K, Praveen Rao V, Ranga M, Reddy M. Suryanarayana R, Sharma PS (2007) Response of maize (Zea mays) hybrid and composite to different levels of nitrogen. Indian Journal Agricultural Science 67 : 424-425.

Singh A, Vyas AK Singh AK (2010a) Effect of nitrogen and zinc application on growth, yield and net returns of maize. Annal of Agricultural Research 21 : 296-297.

Singh DP, Rana NS, Singh RP (2006) Growth and yield of winter maize (Zea mays L.) as influenced by intercrop and nitrogen application. Indian Journal of Agronomy 45: 515-519.

Singh MK, Singh RN, Singh SP, Yadav MK, Singh VK (2010b) Integrated nutrient management for higher yield, quality and profitability of baby corn (Zea mays). Indian Journal of Agronomy $55: 100-104$.

Singh SD (2011) Effect of irrigation regimes and nitrogen levels on growth, yield and quality of baby corn. Madras Agriculture Journal $88: 367-370$.

Subramanian RLJr, Manonand SV, Rhoads FM (2006) Effect of time, rate, and increment of applied fertilizer on nutrient plant uptake and yield of corn (Zea mays L.). Proceedings of Soil Science 36: 181-184.

Suryavanshi VP, Chavan BN, Jadhav KT, Pagar PA (2008) Effect of spacing, nitrogen and phosphorous levels on growth, yield and economics of Kharif maize. International Journal of Tropical Agriculture 26 : 287-291.

Thakur DR, Om Prakash, Kharwara PC, Bhalla SK (2007) Effect of nitrogen and plant spacing on growth, yield and economics of baby corn (Zea mays L.). Indian Journal Agronomy 42: 479-483.

Journal of Experimental Biology and Agricultural Sciences http://www.jebas.org 
Thakur DR, Sharma V (2009) Effect of varying rates of nitrogen and its schedule of split application in baby corn (Zea mays). Indian Journal Agricultural Science 69 : 93-95.

Tohidi M, Ahmad N, Seyedata Allah S, Ahahram L (2012) Variables Productivity of Light Interception in Grain Maize Hybrids at Various Amount of Nitrogen. World Applied Sciences Journal $16: 86-93$.

Torbert HA, Potter KN, Morrison JE Jr (2011) Tillage system, fertilizer nitrogen rate, and timing effect on corn yields in the Texas Blackland Prairie. Agronomy Journal 93:1119-1124.

Ummed S, Saad AA, Ram T, Chand L, Mir SA, Aga FA (2012) Productivity, economics and nitrogen-use efficiency of speciality corn (Zea mays) as influenced by planting geometry and nitrogen fertilization. Indian Journal of Agronomy 57 : 43-48.

Wells KL, Blitzer MJ (1984) Nitrogen management in no-till system. pp. 535-549.

Wells LF, Mulvaney DL, Oldham MG, Boone LV, Pendleton JW (2012) Corn yields with fall, spring, and side-dress nitrogen. Agronomy Journal 63: 119-123. 